\title{
Aquaporin 5 Expression and Its Relationship to Apoptosis in Different Grades of Differentiated Non-Small Cell Lung Carcinoma
}

\author{
Fidelis Chibhabha1,2, Yaqiu Li1,3, Yanyong Hao ${ }^{4}$, Hui Zhao', Liming Hao ${ }^{1 *}$ \\ ${ }^{1}$ Department of Histology and Embryology, School of Basic Medical Sciences, Norman Bethune College of \\ Medicine, Jilin University, Changchun, China \\ ${ }^{2}$ Department of Anatomy, Faculty of Medicine, Midlands State University, Gweru, Zimbabwe \\ ${ }^{3}$ Department of Human Anatomy, Jilin Medical College, Jilin City, China \\ ${ }^{4}$ Department of Pathology, Jilin Province Cancer Hospital, Changchun, China \\ Email: "hlmchlf@126.com
}

Received 13 January 2016; accepted 28 March 2016; published 31 March 2016

Copyright @ 2016 by authors and Scientific Research Publishing Inc.

This work is licensed under the Creative Commons Attribution International License (CC BY). http://creativecommons.org/licenses/by/4.0/

(c) (i) Open Access

\section{Abstract}

Aquaporin 5 has been recently found as an important oncogenic marker whose expression levels seem to be determined by the level of cellular differentiation. Despite aquaporin volume decrease (AVD) being the most conserved earliest event in apoptosis, there is still a paucity of studies exploring on aquaporin expression and its relationship with apoptosis in cancer. The aim of this study was to investigate the expression of aquaporin 5 channel protein and to explore on its relationship with apoptosis in well and poorly differentiated non-small cell lung carcinoma both in-vivo and in-vitro. Findings from the study showed that the expression of AQP5 both in-vivo and in-vitro was dependent on the type and degree of tumour differentiation. In-vivo, an increase in aquaporin 5 expression was associated with an increased apoptosis in both poorly and highly differentiated adenocarcinoma (AC) while there was no association between aquaporin 5 expression and apoptosis in both poorly and highly differentiated squamous cell carcinoma (SCC). In vitro, differentiation therapy in the form of ATRA decreased both cell proliferation and increased the expression of AQP5 in A549 cells. The cytomorphological changes, expression of differentiation markers and flow cytometry apoptotic results were dependent on the dose of ATRA treatment. In conclusion, a higher expression of aquaporin 5 was found to promote the rate of the apoptotic process in lung adenocarcinoma $(\mathrm{AC})$.

\footnotetext{
${ }^{*}$ Corresponding author.
} 
Keywords

Aquaporin 5, Non-Small Cell Carcinoma, Apoptosis, Apoptotic Index

\section{Introduction}

Aquaporins are integral membrane channel proteins that regulate water and small solute movement across membranes in both physiological and pathological conditions [1]-[3]. In cancer, increased aquaporin expression levels have been reported in aggressive tumours of various origins and a link between aquaporin expression and the level of histological tumour grade of cancer has been described [4]-[8]. The increased aquaporin expression in cancer cells has been implicated to play a major role in the rapid penetration of water into the growing tumour to meet the high energy demands of rapid replication and multiplication [9]. Studies where the over-expression of AQP5 was associated with an increased rate of cell migration, proliferation and invasiveness of cancer cells include those of the cancers of the colon [7], ovary [10], pancreas [11], stomach [12], bone [13] and the lungs [14].

Apoptosis is a programmed cell death process characterized by distinct morphological features and biochemical processes that was first described by Kerr et al., in 1972 [15]. In cancer, apoptosis remains a complex biochemical process in which the balance between cellular proliferation and cell death has been shown to play a critical role in tumour progression [16]. Of note is that the earliest morphological event of apoptosis is water loss accompanied by subsequent volume decrease which has been reported to be aquaporin mediated in lymphocytes and ovarian cells [17] [18]. However, other studies have suggested that cell volume water losses alone are not always sufficient for the triggering and progression of cell death [19] [20]. With regards to AQP5 expression in apoptosis, current research has demonstrated that AQP5 increased expression inhibited apoptosis in chronic myelogenous leukemia while it enhanced apoptosis in differentiating bone marrow derived mesechymal cells [13] [21]. Unfortunately, no similar study has been done for the lung cancer despite it being the leading cause of cancer related deaths in the China [22]. Therefore the aim of this study was to investigate the expression of AQP5 in cancer cells and to find its relationship to apoptosis in various grades of differentiated non-small cell lung cancer.

\section{Materials and Methods}

\subsection{Tissue Study}

The tissue specimens study included 40 specimens of non-small cell lung cancer (NSCLC) subtypes that were confirmed by histopathological analysis after surgical resection at the Jilin Province Tumor Hospital, from October 2014 to January 2015. The study protocol was approved by the Institutional Review Board of Jilin University and all participants signed an informed consent form. The patients' ages ranged from 44 to 84 years, and no radiotherapy or chemotherapy treatment had been given to these subjects. Paraffin-embedded blocks of surgically resected and adjacent non-tumor lung cancer tissues were prepared.

\subsection{Tissue Immunohistochemistry and Cell Diameter Measurement}

Formalin-fixed tissues were embedded in paraffin, sectioned to $5 \mu \mathrm{m}$, and mounted on glass slides. The sections were dewaxed and rehydrated through descending grades of alcohol to distilled water followed by heat induced antigen retrieval in $0.01 \mathrm{M}$ citrate buffer. The sections were blocked with endogenous peroxidase using 3\% (v/v) hydrogen peroxidase in phosphate-buffered saline (PBS). They were washed in $0.01 \mathrm{M}$ PBS and blocked with sheep serum (Beijing Zhongshan Biotechnology) for 2 hours, then incubated overnight at 4 degrees celsius with a monoclonal AQP5 antibody (diluted 1:200, from Beijing Biosynthesis Biotechnology Company). Following subsequent washes in PBS, the sections were incubated with a secondary antibody (Beijing Zhongshan Biotechnology) for 20 minutes at room temperature and later the peroxidase antiperoxidase complex. Immunoreactivity was demonstrated using diaminobenzadine (Fuzhou New Biotechnology Development Company) which produced a brown insoluble precipitate at immunopositive sites. The sections were counterstained with hematoxylin and mounted on a cover glass. The negative controls were incubated with $0.01 \mathrm{M}$ PBS without the primary antibody. After observation under the microscope, pictures were taken using a Nikon camera (Japan, 16 megapixels) at $200 \times$ magnification. The cell diameter was measured under a calibrated protocol while the integraloptical density (IOD) to determine AQP5 expression was measured using Image-Pro-Plus Version 6.0. 


\subsection{The Tissue TUNEL Staining Method}

Tissue apoptosis was detected by the terminal deoxynucleotidyl transferase-mediated deoxyuridine triphosphatebiotin nick end-labeling (TUNEL) method, which detects not only cells with typical morphologic features of apoptosis but also cells in an earlier stage of apoptosis showing no apparent morphological change. After TUNEL staining procedure, counterstaining was performed with hematoxylin. For negative controls, the terminal deoxynucleotidyl transferase was omitted. Ten fields of 100 cells each were randomly chosen from different parts of the tumor sections. The numbers of apoptotic cells and the number of malignant cells in each field were recorded and expressed as the apoptotic index (number of apoptotic cells per 1000 malignant cells).

\subsection{Cell Culture Study}

The human tumorigenic lung epithelial cell line A549 was obtained from American Type Culture Collection (USA). The cells were maintained in high glucose DMEM supplemented with $10 \%$ fetal bovine serum and $1 \%$ of penicillin-streptomycin at $37^{\circ} \mathrm{C}$ in a $5 \% \mathrm{CO}_{2}$ incubator. On reaching $75 \%$ confluency, the A549 cells were washed with $0.01 \mathrm{M}$ PBS and then removed from the flask by the addition of $0.25 \%$ trypsin.

\subsection{ATRA Induction of Differentiation and the MTT Proliferation Study}

The MTT assay (3-[4,5-dimethylthiazol-2-yl]-2, 5-diphenyltetrazolium bromide) was used to determine cell growth rates. Cells were grown in 96-well plates in 10\% FBS-containing medium at an initial density of $2 \times 10^{3}$ cells per well. After 24 hrs, the wells were treated with various concentrations of all trans-retinoic acid 1, 2.5, 5.0, 7.5, 10, 12.5, 15, and $20 \mu \mathrm{g} / \mathrm{ml}$. After 24, 48 and $72 \mathrm{hrs,} 20 \mathrm{ul}$ of MTT solution was added, and plates were incubated at $37^{\circ} \mathrm{C}$ for $4 \mathrm{hrs}$. Media was then aspirated, and the formazan formed was solubilized with $150 \mu \mathrm{l}$ DMSO. Cell viabilities were measured as individual well absorbances at $570 \mathrm{~nm}$ using a microplate reader. The cell viability absorbance was based on the absorbance of untreated cells which was considered as $100 \%$. The results were determined by three independent experiments.

\subsection{Measurement of A549 Reversal of Phenotype and Differentiation}

The morphological changes of A549 cells after 72 hrs ATRA treatments were examined and pictures taken. The aspect ratios of the cells (ratio of width to length) and area were calculated using the Image-Pro-Plus Version 6.0 Program that included 50 cells in each picture of Figure 3. To determine whether differentiation and reversal of malignant phenotype of A549 cells the expression of MUC5AC (and other associated mucins) and CEA in A549 cells was examined by Alcian Blue/Periodic acid Schiff staining and immunohistochemical assay respectively.

\subsection{A549 Cell Immunocytochemistry and Immunoflorescence.}

The protein expression of CEA in A549 cells was examined by immunohistochemistry using the anti-CEA mAb. A549 cells were seeded on sterile glass cover slides for 24 hours and then treated with ATRA at 5, 10 and 15 $\mu \mathrm{g} / \mathrm{ml}$ for 72 hrs. Following treatment, the cells were stained using the Ultra Sensitive ${ }^{\mathrm{TM}}$ Immunohistochemical Staining Kit (Maixin Bio, Fuzhou, P.R. China) according to the manufacturer's instructions. Immunolocalization was done using DAB as a chromogen. Slides were counterstained with hematoxylin before dehydration and mounting. The intensity of the immunoreactivity was analyzed using the Image-Pro Plus (Media Cybernetics) Version 6 software. For AQP5 immunoflorescence assay, the cultured cells, after treatment with retinoic acid of varying concentrations were washed three times with PBS and fixed in 4\% paraformaldehyde (PFA) for 15 mins. The fixed cells were covered with $0.01 \mathrm{M}$ PBS, treated with $10 \%$ donkey serum to block any non-specific binding, and the slides labeled with the rabbit AQP5mAb (1:200). After overnight incubation at $4^{\circ} \mathrm{C}$, the cells were washed in PBS and then incubated with anti-rabbit Alexa 488 as the secondary antibody. An hour later, the slides were washed in PBS at $37^{\circ} \mathrm{C}$ and stained with Hoechst 33342 for 15 minutes. After washing in PBS, slides were mounted in $40 \%$ glycerol and finally examined under a fluorescence microscope.

\subsection{Annexin V/PI Staining and Flow Cytometry}

A549 cells were incubated with varying concentrations of all trans-retinoic acid (0, 5, 10 and $15 \mu \mathrm{g} / \mathrm{ml})$ for $72 \mathrm{~h}$. The cells $\left(>1 \times 10^{6}\right)$ were harvested from each group for the Annexin V-fluorescein isothiocyanate (FITC) and 
PI double-staining apoptosis assay. Following centrifugation at $1000 \mathrm{rpm}$ for 3 minutes of the harvested cells, the pellets were re-suspended in $100 \mu \mathrm{l} 1 \mathrm{X}$ binding buffer with $5 \mu \mathrm{l}$ Annexin V and $5 \mu \mathrm{l} \mathrm{PI}$. After incubation for 15 minutes in the dark, the samples were taken for flow cytometry. Flow cytometry data analysis was done using the Lysis software. In total, $\geq 10,000$ events were analyzed for each sample.

\subsection{Statistical Analysis}

SPSS version 19 software (Chicago, IL) was used for data analysis. Descriptive statistics were used to describe data. Continuous data were compared using Student's t test, if the distribution of samples followed a normal distribution, using the $0.05 \%$ level of significance. For correlation analysis the Spearman's rank correlation value was used ( $\mathrm{p}<0.01$ was regarded as significant).

\section{Results}

\subsection{Diameter of Cancer Cells and Mean Optical Density in Lung Squamous Cell Carcinoma (SCC) and Adenocarcinoma (AC)}

In squamous cell lung carcinoma the mean optical density of the well-differentiated squamous cell carcinoma $(0.283 \pm 0.02)$, was significantly higher than that in poorly differentiated squamous cell carcinoma group $(0.219$ $\pm 0.05)(\mathrm{p}<0.05)$, while the diameter of well-differentiated cancer cells $(27.02 \pm 0.83)$ was significantly higher than that of poorly differentiated squamous cell carcinoma $(17.85 \pm 0.82)(p<0.05)$. For lung adenocarcinoma the diameter of well-differentiated adenocarcinoma (13.60 \pm 0.82) was significantly lower than that of poorly differentiated lung adenocarcinoma cells $(28.01 \pm 1.01)(\mathrm{p}<0.05)$, while the mean optical density of the well-differentiated group $(0.281 \pm 0.03)$ was significantly higher than that in poorly differentiated lung adenocarcinoma group $(0.238 \pm 0.02)(\mathrm{p}<0.05)$ (Figure $1 \&$ Table 1$)$.

\subsection{Apoptotic Indices (per 1000 Cells) for Lung Squamous Cell Carcinoma (SCC) and Adenocarcinoma (AC)}

The values for apoptotic index for squamous cell carcinoma ranged from 14 to 23 apoptotic cells per 1000 cells (Figure 2). The apoptosis index (per 1000 cells) of well differentiated lung squamous cell carcinoma group $(19.93 \pm 2.37)$ was significantly higher than that in poorly differentiated lung squamous cell carcinoma group $(17.27 \pm 1.80)(p<0.05)$. The apoptosis index (per 1000 cells) of well-differentiated adenocarcinoma group $(20.20 \pm 2.40)$ was significantly higher than that in poorly differentiated adenocarcinoma group $(18.53 \pm 1.73)$ $(\mathrm{p}<0.05)$

\subsection{Correlations between Diameters, Mean Optical Density and Apoptotic Indices}

Table 2 shows the correlation coefficients (Spearman's Rank correlation values) between MOD and AI. For correlation analysis, no significant correlation was found in both high and poorly differentiated squamous cell groups between mean optical density and the apoptosis index ( $p>0.05)$. In both high and poorly differentiated adenocarcinoma tissues, significant correlation was found between MOD and AI as shown in Table 2.

\subsection{ATRA Induction of Differentiation and the MTT Proliferation Study}

Figure 3 shows a dose and time dependent effect on cell viability and proliferation of A549 cells following ATRA treatment. ATRA treatment of $2.5 \mu \mathrm{g} / \mathrm{ml}$ concentration was ineffective for growth inhibition after 24, 48 and 72 hours of treatment. Significant decrease in cell proliferation started from $5 \mu \mathrm{g} / \mathrm{ml}$ ATRA treatment in all the 3 groups. Cell viability was decreased to less than 50\% after $20 \mu \mathrm{g} / \mathrm{ml}$ ATRA treatment for 48 hours and $12.5 \mu \mathrm{g} / \mathrm{ml}$ ATRA for 72 hours. The IC50 values for ATRA for 48, 72 and 96 hrs were 20.96, 16.81 and 11.37 $\mu \mathrm{g} / \mathrm{ml}$ respectively.

\subsection{A549 Cytomorphological Changes after ATRA Treatment for 72 Hours}

Quantitative analysis of the cells in Figure 4 after treatment of various concentrations of ATRA for 72 hours was done and the results are shown in Table 3. 

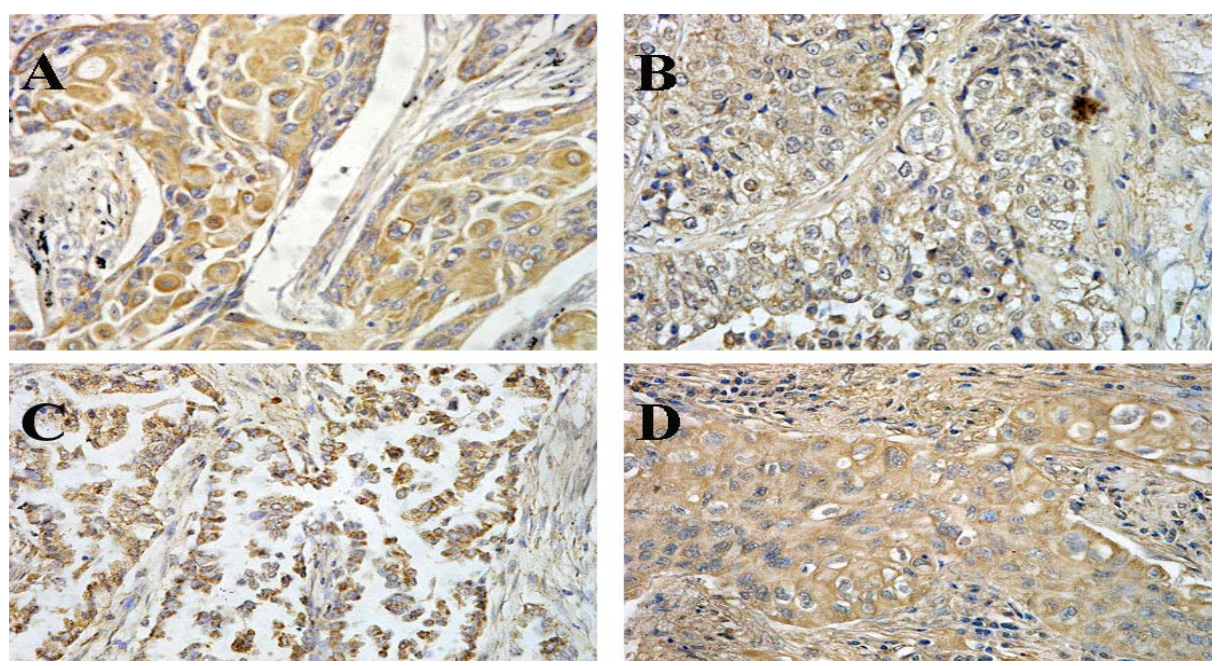

Figure 1. AQP5 tissue immunohistochemistry brown staining of lung squamous cell carcinoma and adenocarcinoma (AC). A: high differentiated squamous cell carcinoma. B: low differentiated squamous cell carcinoma. C: high differentiated adenocarcinoma D: low differentiated adenocarcinoma. $\times 200$ magnification.

Table 1. Diameters, IOD and mean optical densities for AQP5 expression in lung squamous cell carcinoma (SCC) and adenocarcinoma (AC).

\begin{tabular}{cccc}
\hline Type & Diameter & Integrated Optical Density & Mean Optical Density \\
\hline High differentiated SCC & $27.02 \pm 0.83$ & 397,546 & $0.283 \pm 0.02$ \\
Low differentiated SCC & $17.85 \pm 0.82^{*}$ & 381,515 & $0.219 \pm 0.05^{*}$ \\
High differentiated AC & $13.60 \pm 0.82^{*}$ & 337,903 & $0.281 \pm 0.03^{*}$ \\
Low differentiated AC & $28.01 \pm 1.01^{*}$ & 590,950 & $0.238 \pm 0.02^{*}$ \\
\hline
\end{tabular}

${ }^{*}$ Significant vs untreated control $(\mathrm{p}<0.05)$.
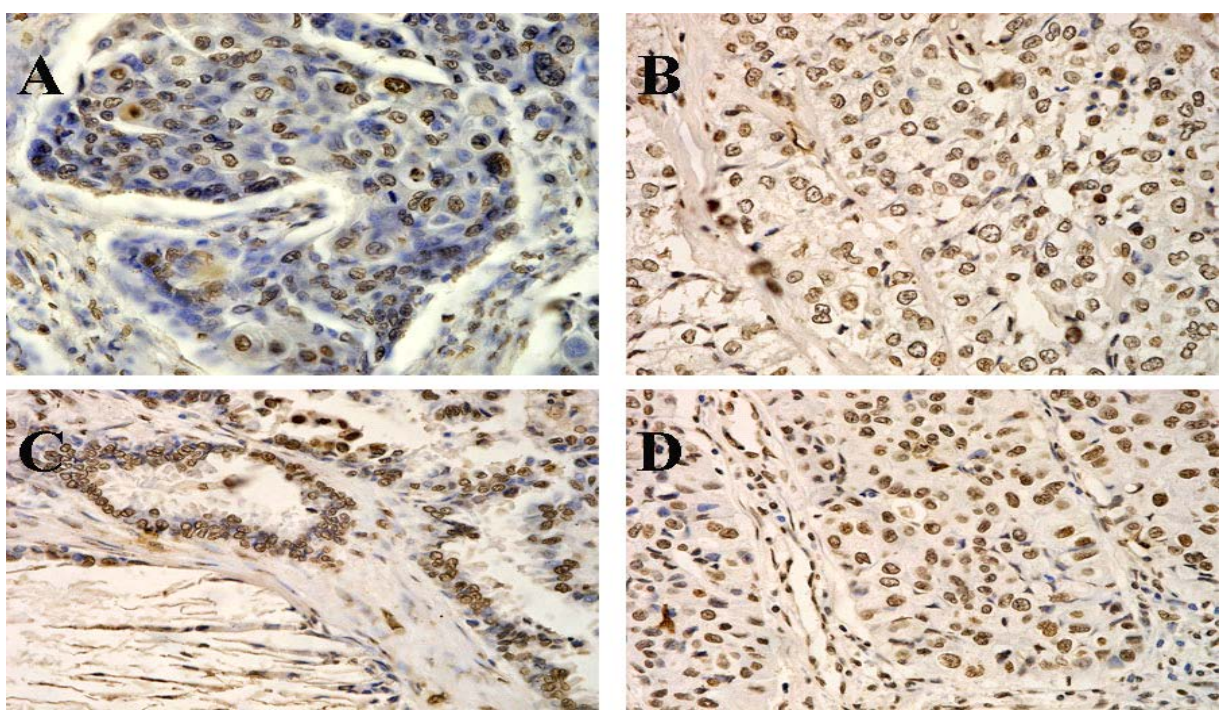

Figure 2. Tissue apoptosis TUNEL staining of lung squamous cell carcinoma and adenocarcinoma (AC). A: high differentiated squamous cell carcinoma, B: low differentiated squamous cell carcinoma, C: high differentiated adenocarcinoma, D: low differentiated adenocarcinoma. $\times 200$ magnification. 
Table 2. Correlation results for mean optical density (MOD) vs. apoptotic index (AI), (per 1000 cells) in lung squamous cell carcinoma (SCC) and adenocarcinoma (AC).

\begin{tabular}{ccc}
\hline Type & $\begin{array}{c}\text { Spearman's Rank } \\
\text { Correlation (r-value) }\end{array}$ & p-value \\
\hline High differentiated SCC & -0.069 & 0.807 \\
Low differentiated SCC & -0.299 & 0.279 \\
High differentiated AC & 0.524 & $0.045^{*}$ \\
Low differentiated AC & 0.661 & $0.007^{* *}$ \\
\hline
\end{tabular}

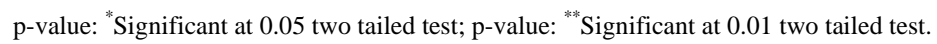

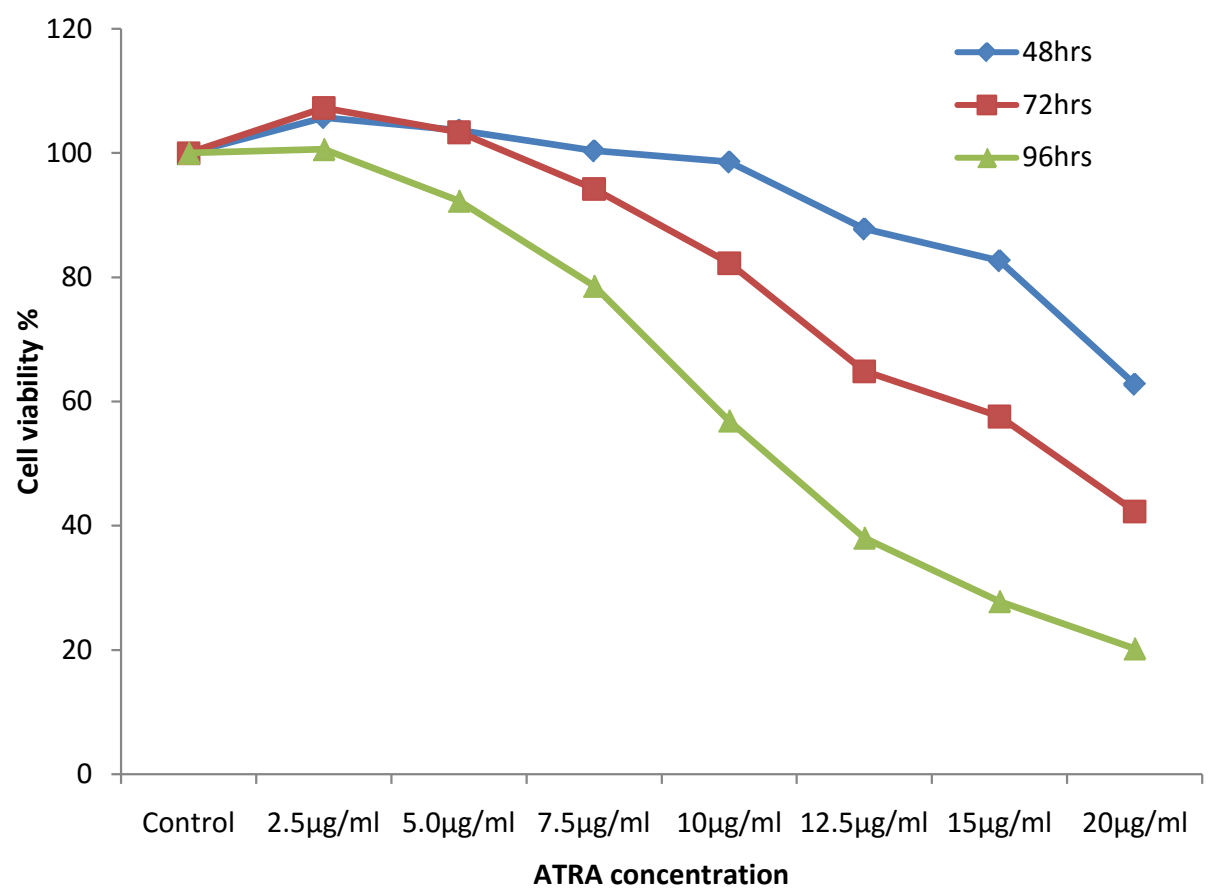

Figure 3. Cell viability following MTT cell proliferation study for A549 cells after ATRA treatment, 48 hrs (blue), 72 hrs (red) and 96 hrs (green).
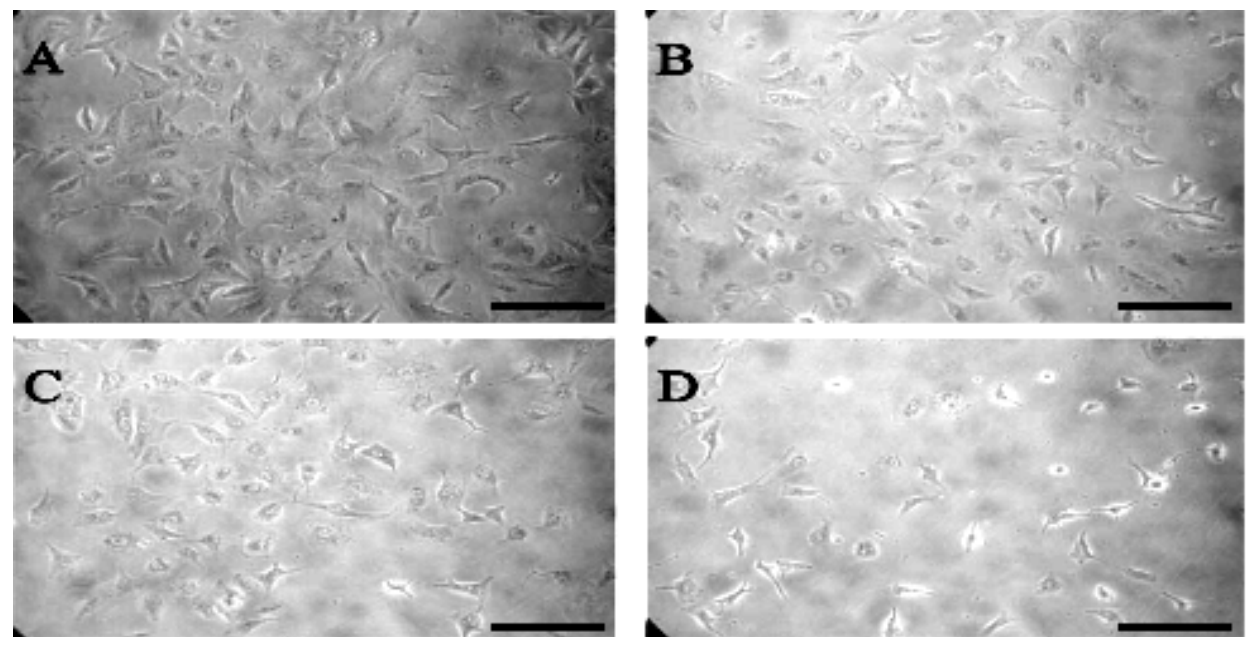

Figure 4. Morphological changes of A549 cells following ATRA treatment for 72 hours. A, no ATRA treatment; B, $5 \mu \mathrm{g} / \mathrm{ml}$ ATRA; C, $10 \mu \mathrm{g} / \mathrm{ml}$; D, $15 \mu \mathrm{g} / \mathrm{ml}$ ATRA treatment. $\times 200$ magnification. 
Table 3. Quantitative analysis of the cell morphological characteristics after ATRA treatment.

\begin{tabular}{ccc}
\hline Concentration of ATRA & Cell Aspect Ratio & Area $\left(\mu \mathrm{m}^{2}\right)$ \\
\hline Control & 1.62 & $2266.4 \pm 24$ \\
$5 \mu \mathrm{g} / \mathrm{ml}$ & 1.57 & $1672.5 \pm 32^{*}$ \\
$10 \mu \mathrm{g} / \mathrm{ml}$ & 1.59 & $1097.5 \pm 54^{*}$ \\
$15 \mu \mathrm{g} / \mathrm{ml}$ & 1.32 & $816.90 \pm 27^{*}$ \\
\hline
\end{tabular}

"Significant vs untreated control $(\mathrm{p}<0.05)$.

\subsection{A549 Reversal of Phenotype and Differentiation}

Mucins (MUC5AC and associated glycoconjugates) and CEA (carcinoembryonic atigen) were taken as markers for measuring the differentiation process of A549 cell using retinoic acid. As shown in Figure 5, the blue colour staining is for acidic mucins, magenta for neutral staining and a mixture of both colours is purple. The results show differences in staining for the mucins. Intense staining for acidic mucins is shown in the non-treated group, followed by the $5 \mu \mathrm{g} / \mathrm{ml}$ group while there is faint staining for both acidic and neutral mucins in the $15 \mu \mathrm{g} / \mathrm{ml}$ ATRA treated group. Figure 6 shows that CEACAM 5 (commonly known as CEA) expression was higher in the untreated group than the treated groups. It can be noted that not all cells secrete CEA, as shown by the brown staining of DAB. The more the confluent the cells are, the more the expression of the carcinoembryonic antigen.

\subsection{A549 Cell Immunohistochemistry and Immunoflorescence}

Figure 7 shows the immunoflorescence expression of aquaporin 5 in A549 cells following ATRA treatment. The images were quantified using Image Pro Plus Version 6 Software and the Mean Optical Densities (IOD) values (per cell) were recorded (Table 4). The untreated cells had the lowest expression of aquaporin 5 per cell and the expression of aquaporin 5 for the treatment groups was dependent on the dose of ATRA.

\subsection{Annexin V/PI Staining and Flow Cytometry}

As shown in Figure 8, the control (no treatment) group had the highest number of dead cells (2.93\%), while the highest concentration of ATRA, $15 \mu \mathrm{g} / \mathrm{ml}$ group had the highest number of cells in early and late apoptosis (7.15\%). The $5 \mu \mathrm{g} / \mathrm{ml}$ ATRA concentration had the highest percentage of cells in late apoptosis. The mean optical densities for aquaporin 5 and the apoptotic indices of A549 cells after ATRA treatment are shown in Table 4.

A significant positive correlation was found between AQP5 expression (MOD) and the percentage of cells in early and late apoptosis $(r=0.970 ; p=0.0304)$ after all trans-retinoic acid (ATRA) treatment of A549 lung adenocarcinoma cells for 72 hours (Table 4). A significant positive correlation was found between AQP5 expression (MOD) and the percentage of cells in early and late apoptosis $(r=0.970 ; p=0.0304)$ after all trans-retinoic acid (ATRA) treatment of A549 lung adenocarcinoma cells for 72 hours (Table 4).

\section{Discussion}

The processes of cellular proliferation and apoptosis have each been shown to play important roles in tumor development but their contributions to tumor progression are still yet to be defined [16]. A detailed examination of surgically resected tissues in this study showed that in squamous cell carcinoma (SCC), the histological degree of differentiation of cancer cells determines the difference in the diameters of the cells and the expression of aquaporin 5. In these cells, well differentiated cells had higher diameters, higher expression of AQP5, and had a higher apoptotic index compared to poorly differentiated SCC. The finding that AQP5 expression is coupled with a lower apoptotic index (AI) in poorly differentiated SCC might explain its aggressiveness and ability to metastasize more than the well differentiated type. In adenocarcinoma (AC), although the diameter of the well differentiated AC was lower than that of low differentiated AC, the relative expression of AQP5 (measured per cell as MOD) and the apoptotic index were significantly higher than those for low differentiated AC. This finding agrees well with the literature which reported an over-expression pattern ratio to be high in well differentiated compared to poorly differentiated AC [14]. A higher expression of AQP5 in poorly differentiated AC than poorly differentiated SCC might also be related to the involvement of the AQP5 channel protein in water permeability of AC cells which are specialized for mucus secretion. 


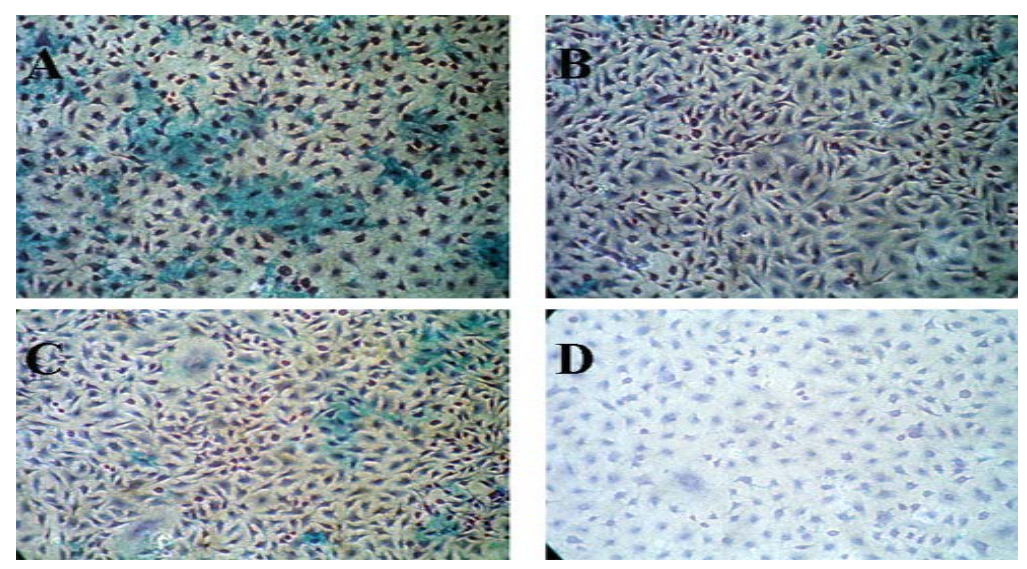

Figure 5. Measurement of A549 reversal of phenotype and differentiation. A549 cells Alcian Blue-Periodic Acid Schiff staining for mucins and other glycoconjugates after 72 hrs ATRA treatment. A, no ATRA treatment; B, 5 $\mu \mathrm{g} / \mathrm{ml}$ ATRA; C, $10 \mu \mathrm{g} / \mathrm{ml}$; D, $15 \mu \mathrm{g} / \mathrm{ml}$ ATRA treatment. $\times 200$ magnification.
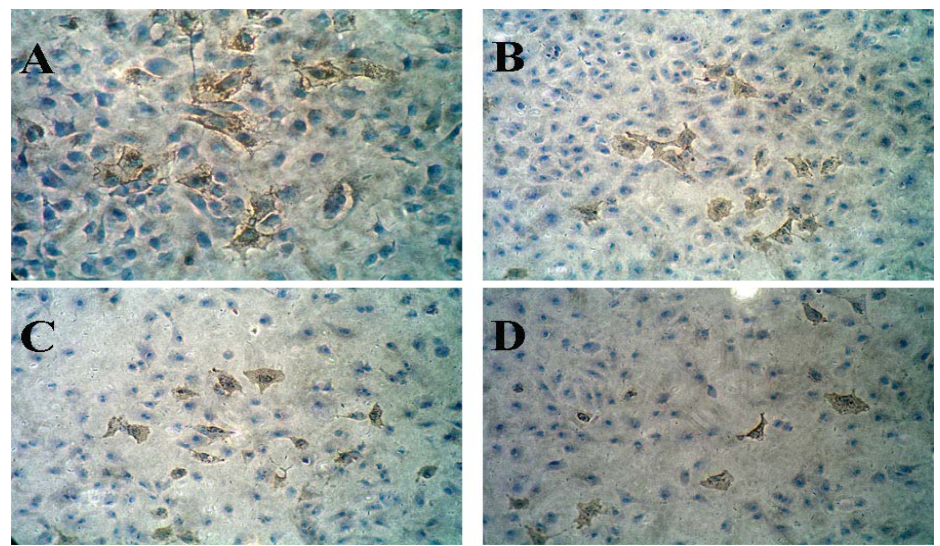

Figure 6. Measurement of A549 reversal of phenotype and differentiation. CEA immmunohistochemistry staining after 72 hours ATRA treatment of A549 cells. A, no ATRA treatment; B, $5 \mu \mathrm{g} / \mathrm{ml}$ ATRA; C, $10 \mu \mathrm{g} / \mathrm{ml}$; D, 15 $\mu \mathrm{g} / \mathrm{ml}$ ATRA treatment. $\times 200$ magnification.
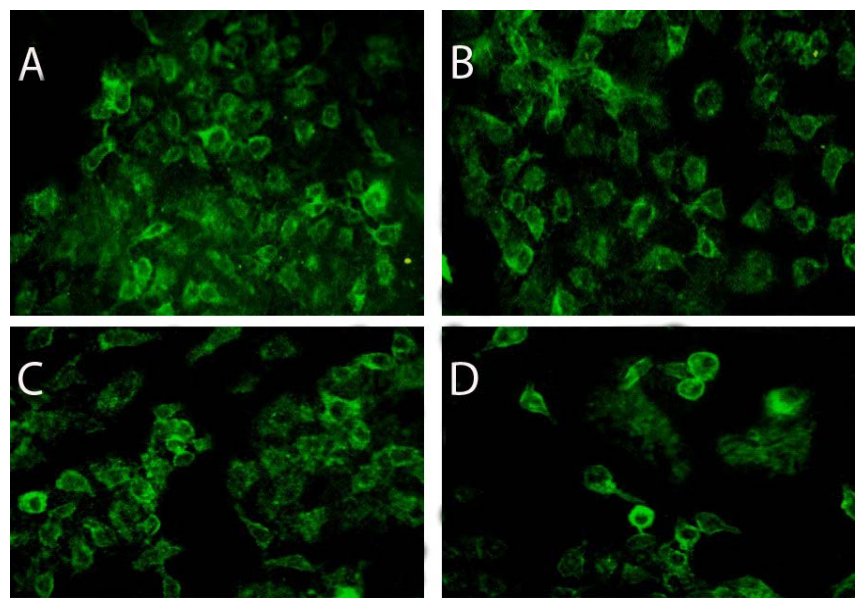

Figure 7. AQP5 immunoflorescence staining after 72 hours of ATRA treatment. A, no ATRA treatment; B, $5 \mu \mathrm{g} / \mathrm{ml}$ ATRA; C, $10 \mu \mathrm{g} / \mathrm{ml}$; D, $15 \mu \mathrm{g} / \mathrm{ml}$ ATRA treatment. $\times 200$ magnification. 
Table 4. Mean optical density for aquaporin 5 and apoptotic index for A549 cells after 72 hours of ATRA treatment.

\begin{tabular}{ccc}
\hline ATRA concentration & $\begin{array}{c}\text { AQP5 Mean Optical } \\
\text { Density }\end{array}$ & $\begin{array}{c}\text { Flow cytometry } \\
\text { Apoptotic index }\end{array}$ \\
\hline Control & $1.2851 \pm 0.14$ & $1.01 \%$ \\
$5 \mu \mathrm{g} / \mathrm{ml}$ & $1.3149 \pm 0.15^{*}$ & $5.67 \%$ \\
$10 \mu \mathrm{g} / \mathrm{ml}$ & $1.3162 \pm 0.10^{*}$ & $6.13 \%$ \\
$15 \mu \mathrm{g} / \mathrm{ml}$ & $1.3351 \pm 0.12^{*}$ & $7.15 \%$ \\
\hline
\end{tabular}

*Significant vs untreated control $(\mathrm{p}<0.05)$.
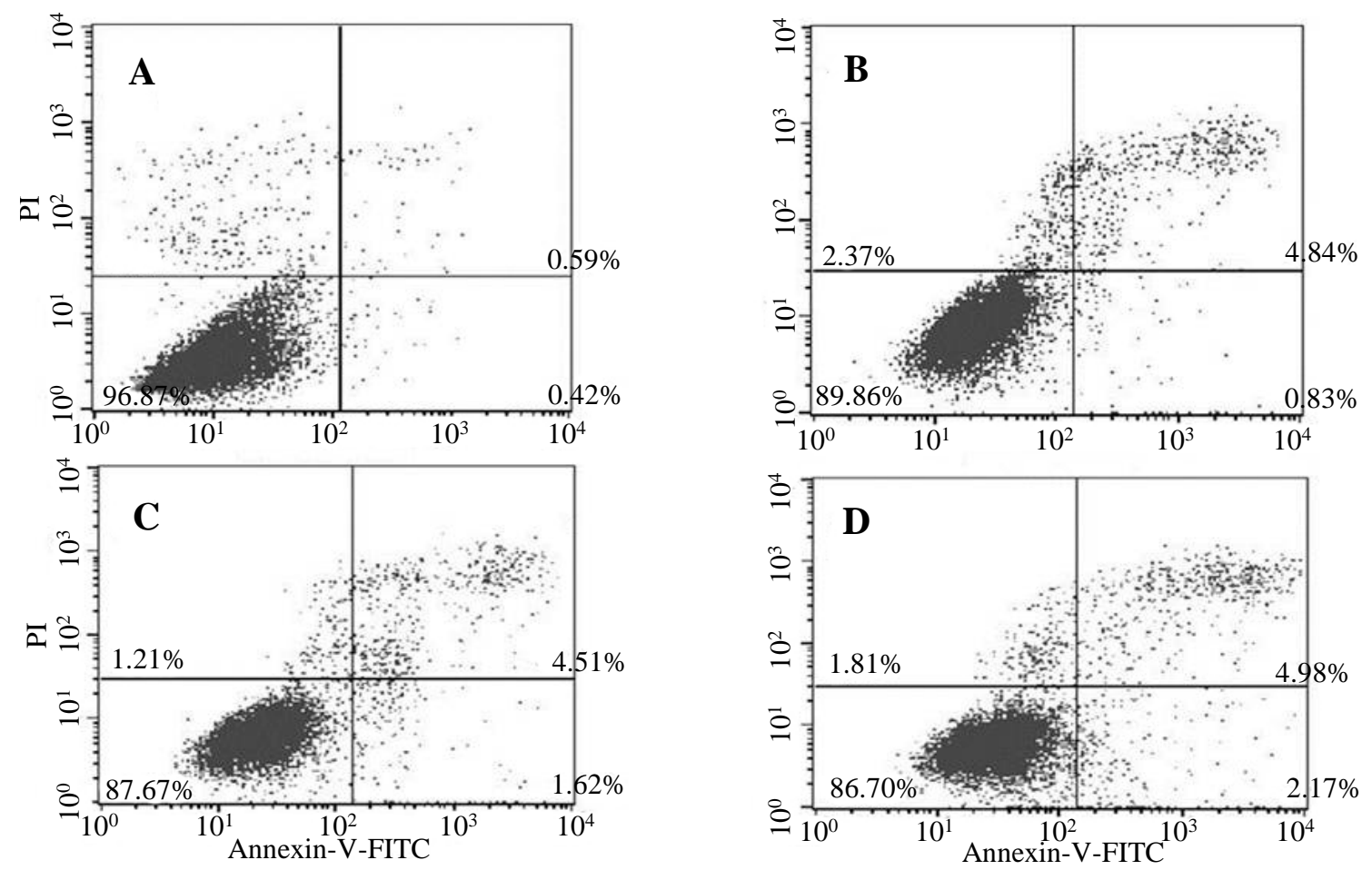

Figure 8. Annexin-V-PI flow cytometry results for A549 cells following ATRA treatment for 72 hours. A, no ATRA treatment; B, $5 \mu \mathrm{g} / \mathrm{ml}$ ATRA; C, $10 \mu \mathrm{g} / \mathrm{ml} ; \mathrm{D}, 15 \mu \mathrm{g} / \mathrm{ml}$ ATRA treatment.

The clinical significance and mechanism of apoptosis in NSCLC has not been fully established, but various authors have reported the apoptotic rate to be an independent prognostic factor in NSCLC [23] [24]. In this study the AI of AC cells $(19.36 \pm 2.22)$ was higher than that of SCC $(18.60 \pm 2.47)$, with a similar pattern following for well differentiated compared to poorly differentiated in both subtypes (SCC and AC) of lung cancer. These results are comparable to the AI per 1000 cells reported previously which found AI in AC (19 \pm 1.7$)$, to be slightly higher than that of squamous cell carcinoma $(18.3 \pm 2.4)$. While other researchers, cautions on the interpretation of the data obtained on apoptosis between different studies [25], data from the present study sought to clearly demonstrate whether AQP5 expression, viewed in relation to apoptosis, had any effect on the apoptosis rate of cancer cells in NSCLC. A statistically significant correlation between MOD and AI was found ( $p<0.05)$, for low differentiated AC ( $p<0.01)$ and high differentiated AC $(\mathrm{p}<0.05)$, while no significant relationship was found between the expression of AQP5 and the apoptotic index $(p>0.05)$ in SCC. From this finding, it can be shown that while AQP5 might be involved in development and progression of lung cancer, it does not have a direct influence on the apoptosis in all the lung cancer subtypes. It therefore implies that, apoptosis still remains a highly complex process with different morphological and biochemical features that are controlled by many different pathways in the different lung cancer subtypes.

Retinoic acid has been found to be an effective differentiation agent and inhibitor of squamous metaplasia in many studies [26]-[31]. Treatment of A549 cells in this study, with various concentrations of ATRA for 24, 48 
and 72 hours showed a dose and time dependent effect on cell proliferation (Figure 3). Although the concentration values of ATRA used in this study seem higher than the previously reported values, these results almost concur with the $10 \mu \mathrm{M}(3 \mu \mathrm{g} / \mathrm{ml})$ concentration of ATRA which has been found to induce differentiation in H226 and A549 cells after 3 days [32]. The directed differentiation of A549 cells through ATRA treatment for 72 hours was carried out in-vitro using mucins and CEA as differentiation markers. The treated cells showed a dose dependent expression of these markers as shown in Figure 5 \& Figure 6. While CEA can be measured from the supernatant of A549 cells, attempts to measure it using electrochemiluminescence method, proved futile in this study. The reasons are still unknown, but it may be explained by the fact that A549 cells contain both tumorigenic (A549-T) and non-tumorigenic cells (A549-NT), which differ in the expression for malignancy markers hence the need to separate the different subpopulations by gradient centrifugation so as to measure the differentiation markers accurately [33].

Results from this experiment show that ATRA induced differentiation of A549 lung adenocarcinoma cells increases the expression of AQP5 per A549 cell (Figure 7). This demonstrates that AQP5 is a putative protein that is involved lung cancer cellular growth and transformation thereby confirming many previous reports in which this protein has been implicated in promotion of tumorigenesis [7] [10] [14] [32] [34]. AQP5 over-expression was also accompanied by some phenotypic changes of lung adenocarcinoma cellular transformation which agrees well with observations made by others researchers, which implicated ectopic AQP5 expression to play a major involvement in human lung cancer growth and metastasis [11] [32]. In this study, ATRA induced differentiation and apoptosis (of $7.15 \%$ after $15 \mu \mathrm{g} / \mathrm{ml}$ ATRA treatment for 72 hours), which can point to the possibility that it might be adequate for therapy if it can be used in combination with other therapeutic agents.

In summary, the cell culture part of this study, showed an increase in the expression of AQP5 per cell (mean optical density) (Figure 7) with increasing dose of ATRA treatment in A549 cells which was significantly correlated to the increase in the apoptosis of A549 cells $(r=0.970 ; p=0.0304)$ (Figure $8 \&$ Table 4). These results concur with the findings in the AC tissue part of this study which also found a statistically significant correlation between mean optical density for both high $(\mathrm{p}<0.01)$ and poorly differentiated AC $(\mathrm{p}<0.05)$. Based on these findings it can therefore be seen that, a higher expression of aquaporin 5 both in-vivo and in-vitro promotes the rate of the apoptosis process in lung AC which is similar to a study where over-expression of AQP-1 in Chinese hamster ovary cells was found to enhance the rate of apoptosis [35]. From this line of thinking, it may be suggested that apoptosis was a result of ATRA induced A549 growth inhibition. This agrees well with studies of apoptosis where a decrease in cell volume (AVD) of whatever cause was found to create an intracellular environment conducive to the activation of the caspase death machinery [17] [18] [20] [35]. Therefore, this means that development of effective differentiation modulators for AQP5 might go a long way in opening a less toxic therapeutic intervention for lung cancer.

In conclusion, AQP5 expression either in-vivo or in-vitro is dependent on the level of cellular differentiation. In both SCC and AC tissues, the well differentiated the cells are so is the higher expression of AQP5 and the apoptotic index. In-vivo, the apoptotic index of AC is higher than that of SCC, while the expression of AQP5 has a more significant effect on the increase of apoptosis in low differentiated than well differentiated AC subtypes. The more the expression of AQP5, the higher is the apoptotic rate. However, no association exists between the expression of AQP5 and apoptotic index in both high and poorly differentiated SCC, an indication that in the body, the apoptotic process, although highly conserved, its progress varies in tissues of different differentiation states. As a differentiation agent, all-trans retinoic acid (ATRA) decreased cell proliferation but increased the expression of AQP5 per cell (calculated as MOD) in A549 cells. The increase in AQP5 per cell which was associated with an increase in apoptosis was significant in A549 cells, a result similar to the tissue study. This means a higher expression of aquaporin 5 both in-vivo and in-vitro promotes the rate of apoptotic process in lung AC. Since the study did not explore in depth the underlying molecular mechanism between AQP5, ATRA and the apoptotic process, a recommendation for future studies is made to better understand this area.

\section{Acknowledgements}

This study was supported by the Scientific and Technological Developing Scheme grant of Jilin Province (201015199). 


\section{Conflict of Interest}

The authors declare none.

\section{References}

[1] Walz, T., Fujiyoshi, Y. and Engel, A. (2009) The Aquaporin Structure and Functional Implications. Handbook of Experimental Pharmacology, 190, 31-56.

[2] Kong, H., Sha, L., Fan, Y., Xiao, M., Ding, J., Wu, J. and Hu, G. (2009) Requirement of AQP4 for Antidepressive Efficiency of Fluoxetine: Implication in Adult Hippocampal Neurogenesis. Neuropschopharmacology, 34, 1263-1276. http://dx.doi.org/10.1038/npp.2008.185

[3] Zheng, G., Li, Y., Gu, Y., Chen, X., Zhou, Y., Zhao, S. and Shen, J. (2010) Beyond Water Channel: Aquaporin 4 in Adult Neurogenesis. Neurochemistry International, 56, 651-654. http://dx.doi.org/10.1016/j.neuint.2010.01.014

[4] Saadoun, S., Papadopoulos, M.C., Davies, D.C., Krishna, S. and Bell, B.A. (2002) Aquaporin 4 Expression Is Increased in Odematous Human Brain Tumours. Journal of Neurology, Neurosurgery \& Psychiatry, 72, 262-265. http://dx.doi.org/10.1136/jnnp.72.2.262

[5] Warth, A., Simon, P., Capper, D., Goeppert, B., Tabatabai, G., Herzog, H., Dietz, K., Stubenvoll, F., Ajaaj, R., Becker, R., Weller, M., Meyermann, R., Wolburg, H. and Mittelbronn, M. (2007) Expression Pattern of the Water Channel Aquaporin-4 in Human Gliomas Is Associated with Blood-Brain Barrier Disturbance But Not with Patient Survival. Journal of Neuroscience Research, 85, 1336-1345. http://dx.doi.org/10.1002/jnr.21224

[6] Otterbach, F., Calliers, R., Kimmig, R., Schmid, K.W. and Bankfalvi, A. (2008) Aquaporin-1 Expression in Invasive Breast Carcinoma. Der Pathologe, 29, 357-362. http://dx.doi.org/10.1007/s00292-008-1039-6

[7] Kang, S.K., Chae, Y.K., Woo, J., Kim, S.K., Park, J.C., Lee, J., Soria, J.C., Jang, J.S., Sidransky, D. and Moon, C. (2008) Role of Human Aquaporin 5 in Colorectal Carcinogenesis. The American Journal of Pathology, 173, 518-525. http://dx.doi.org/10.2353/ajpath.2008.071198

[8] Nico, B. and Ribatti, D. (2010) Aquaporins in Tumor Growth and Angiogenesis. Cancer Letters, 28, 135-138. http://dx.doi.org/10.1016/j.canlet.2010.02.005

[9] Moon, C., Soria, J.C., Jang, S.J., Lee, J., Hoque, M.O., Sibony, M., Trink, B., Chang, Y.S., Sidransky, D. and Mao, L. (2003) Involvement of Aquaporins in Colorectal Carcinogenesis. Oncogene, 22, 6699-6703. http://dx.doi.org/10.1038/sj.onc.1206762

[10] Yang, J.H., Shi, Y.F., Cheng, Q. and Deng, L. (2006) Expression and Localization of Aquaporin 5 in the Epithelial Ovarian Tumours. Gynecologic Oncology, 100, 294-299. http://dx.doi.org/10.1016/j.ygyno.2005.08.054

[11] Woo, J., Lee, J. and Chae, Y.K. (2008) Overexpression of AQP5, a Putative Oncogene, Promotes Cell Growth and Transformation. Cancer Letters, 264, 54-62. http://dx.doi.org/10.1016/j.canlet.2008.01.029

[12] Huang, Y.H., Zhou, X.Y., Wang, H.M., Xu, H., Chen, J. and Lu, N.H. (2013) Aquaporin 5 Promotes the Proliferation and Migration of Human Gastric Carcinoma Cells. Tumour Biology, 34, 1743-1751. http://dx.doi.org/10.1007/s13277-013-0712-4

[13] Yi, F., Khan, M., Gao, H., Hao, F., Sun, M., Zhong, L., Lu, C., Feng, X. and Ma, T. (2012) Increased Differentiation Capacity of Bone Marrow-Derived Mesenchymal Stem Cells in Aquaporin 5 Deficiency. Stem Cells and Development, 21, 2495-2507. http://dx.doi.org/10.1089/scd.2011.0597

[14] Machida, Y., Ueda, Y., Shimasaki, M., Sato, K., Sagawa, M., Katsuda, S. and Sakuma, T. (2010) Relationship of Aquaporin 1, 3, and 5 Expression in Lung Cancer Cells to Cellular Differentiation, Invasive Growth and Metastatis Potential. Human Pathology, 42, 669-678. http://dx.doi.org/10.1016/j.humpath.2010.07.022

[15] Kerr, J.F.R., Wyllie, A.H. and Currie, A.R. (1972) Apoptosis: A Basic Biological Phenomenon with Wide-Ranging Implications in Tissue Kinetics. British Journal of Cancer, 26, 239-257. http://dx.doi.org/10.1038/bjc.1972.33

[16] Mattern, J. and Volm, M. (2004) Imbalance of Cell Proliferation and Apoptosis during Progression of Lung Carcinomas. Anticancer Research, 24, 4243-4246.

[17] Hughes Jr., F.M., Bortner, C.D., Purdy, G.P. and Cidlowski, J.A. (1997) Intracellular K ${ }^{+}$Suppresses the Activation of Apoptosis in Lymphocytes. The Journal of Biological Chemistry, 272, 30567-30576. http://dx.doi.org/10.1074/jbc.272.48.30567

[18] Perez, G.I., Maravei, D.V., Trbovich, A.M., Cidlowski, J.A., Tilly, J.L. and Hughes Jr., F.M. (2000) Identification of Potassium-Dependent and -Independent Components of the Apoptotic Machinery in Ovarian Germ Cells and Granulosa Cells. Biology of Reproduction, 63, 1358-1369. http://dx.doi.org/10.1095/biolreprod63.5.1358

[19] Jablonski, E.M., Mattocks, M.A., Sokolov, E., Koniaris, L.G., Hughes, F.M., Fausto, N., Pierce, R. and McKillop, I. (2007) Decreased Aquaporin Expression Leads to Increased Resistance to Apoptosis in Hepatocellular Carcinoma. 
Cancer Letters, 250, 36-46. http://dx.doi.org/10.1016/j.canlet.2006.09.013

[20] Orlov, S.N., Model, M.A. and Grygorczyk, R. (2013) CrossTalk Opposing View: The Triggering and Progression of the Cell Death Machinery Can Occur without Cell Volume Perturbations. The Journal of Physiology, 591, 6123-6125. http://dx.doi.org/10.1113/jphysiol.2013.258624

[21] Chae, Y.K., Sung, K.K., Myoung, S.K., Janghee, W., Juna, L., Steven, C., Dong-Wook, K., Myungshin, K., Seonyang, P., Inho, K., Bhumsuk, K., Jiyoung, R., Nam, H.K., Gyeongsin, P., Soo-Hyun, K., Se-Eun, J., Il-Young, K., David, S. and Chulso, M. (2008) Human AQP5 Plays a Role in the Progression of Chronic Myelogenous Leukemia (CML). PLoS ONE, 3, e2594. http://dx.doi.org/10.1371/journal.pone.0002594

[22] Chen, W., Zheng, R., Baade, P.D., Zhang, S., Zeng, H., Bray, F., Jemal, D.V.M., Yu, X.Q. and He, J. (2015) Cancer Statistics in China, 2015. CA: A Cancer Journal for Clinicians, 66, 115-132. http://dx.doi.org/10.3322/caac.21338

[23] Tormanen, U., Eerola, A.K., Rainio, P., Vähäkangas, K., Soini, Y., Sormunen, E., Bloigu, R., Lehto, V.-P. and Pääkkö, P. (1995) Enhanced Apoptosis Predicts Shortened Survival in Non-Small Cell Lung Carcinoma. Cancer Research, 55, 5595-5602.

[24] Tanaka, F., Kawano, Y., Li, M., Takata, T., Miyahara, R., Yanagihara, K., Ohtake, Y., Fukuse, T. and Wada, H. (1999) Prognostic Significance of Apoptotic Index in Completely Resected Non-Small-Cell Lung Cancer. Journal of Clinical Oncology, 17, 2728-2736.

[25] Potten, C.S. (1996) What Is an Apoptotic Index Measuring? A Commentary. British Journal of Cancer, 74, $1743-1748$. http://dx.doi.org/10.1038/bjc.1996.624

[26] Zou, C.P., Kurie, J.M., Lotan, D., Zou, C.C., Hong, W.K. and Lotan, R. (1998) Higher Potency of N-(4-Hydroxyphenyl)retinamide than All-Trans-Retinoic Acid in Induction of Apoptosis in Non-Small Cell Lung Cancer Cell Lines. Clinical Cancer Research, 4, 1345-1355.

[27] Hansen, L.A., Sigma, C.C., Andreola, F., Ross, S.A., Kelloff, G.S. and De Luca, L.M. (2000) Retinoids in Chemoprevention and Differentiation Therapy. Carcinogenesis, 21, 1271-1279. http://dx.doi.org/10.1093/carcin/21.7.1271

[28] Choi, E.J., Whang, Y.I., Kim, S.K., Kim, J.H. and Kim, Y.H. (2007) Combinational Treatment with Retinoic Acid Derivatives in Non-Small Cell Lung Carcinoma in Vitro. Journal of Korean Medical Science, 22, S52-S60. http://dx.doi.org/10.3346/jkms.2007.22.S.S52

[29] Roy, R., Willan, P.M., Clarke, R. and Farnie, G. (2010) Differentiation Therapy: Targeting Breast Cancer Stem Cells to Reduce Resistance to Radiotherapy and Chemotherapy. Breast Cancer Research, 12, O5. http://dx.doi.org/10.1186/bcr2496

[30] So, P.L., Fujimoto, M.A. and Epstein Jr., E.H. (2008) Pharmacologic Retinoid Signaling and Physiologic Retinoic Acid Receptor Signaling Inhibit Basal Cell Carcinoma Tumorigenesis. Molecular Cancer Therapeutics, 7, 1275-1284. http://dx.doi.org/10.1158/1535-7163.MCT-07-2043

[31] Chang, Q., Chen, Z., You, J., McNutt, M.A., Zhang, T., Han, Z., Zhang, X., Gong, E. and Gu, J. (2007) All-Trans-Retinoic Acid Induces Cell Growth Arrest in a Human Medulloblastoma Cell Line. Journal of Neuro-Oncology, 84, 263267. http://dx.doi.org/10.1007/s11060-007-9380-9

[32] Zhang, Z., Chen, Z., Song, Y., Zhang, P., Hu, J. and Bai, C. (2010) Expression of Aquaporin 5 Increases Proliferation and Metastasis Potential of Lung Cancer. Journal of Pathology, 221, 210-220. http://dx.doi.org/10.1002/path.2702

[33] Singer, B.B., Scheffrahn, I., Kammerer, R., Suttorp, N., Ergun, S. and Slevogt, H. (2010) Deregulation of the CEACAM Expression Pattern Causes Undifferentiated Cell Growth in Human Lung Adenocarcinoma Cells. PLoS ONE, 5, e8747. http://dx.doi.org/10.1371/journal.pone.0008747

[34] Jung, H.J., Park, J.-Y., Jeon, H.-S. and Kwon, T.-H. (2011) Aquaporin-5: A Marker Protein for Proliferation and Migration of Human Breast Cancer Cells. PLoS ONE, 6, e28492. http://dx.doi.org/10.1371/journal.pone.0028492

[35] Jablonski, E.M., Webb, A.N., McConnell, N.A., Riley, M.C. and Hughes Jr., F.M. (2004) Plasma Membrane Aquaporin Activity Can Affect the Rate of Apoptosis but Is Inhibited after Apoptotic Volume Decrease. American Journal of Physiology-Cell Physiology, 286, C975-C985. http://dx.doi.org/10.1152/ajpcell.00180.2003 


\section{Submit or recommend next manuscript to SCIRP and we will provide best service for you:}

Accepting pre-submission inquiries through Email, Facebook, LinkedIn, Twitter, etc.

A wide selection of journals (inclusive of 9 subjects, more than 200 journals)

Providing 24-hour high-quality service

User-friendly online submission system

Fair and swift peer-review system

Efficient typesetting and proofreading procedure

Display of the result of downloads and visits, as well as the number of cited articles

Maximum dissemination of your research work

Submit your manuscript at: http://papersubmission.scirp.org/ 